Олег Яцино, директор Департаменту кадрової політики Міністерства оборони України

\title{
ФОРМИ ТА МЕТОДИ ПІДВИЩЕННЯ КВАЛІФІКАЦІЇ ФАХІВЦІВ СЛУЖБ ПЕРСОНАЛУ ЗБРОЙНИХ СИЛ США
}

У статті проведено аналіз форм та методів навчання, які використовуються в системі підвищення кваліфікації фахівців служб персоналу збройних сил США; розглянуто основні напрями досліджень зарубіжних та вітчизняних науковців у ичій галузі; визначено основні групи методів навчання слухачів та їх складові; проаналізовано особливості використання викладачами курсів підвищення кваліфікачії різноманітних форм та методів навчання в ході проведення занять.

Ключові слова: форми та методи навчання; фахівці служб персоналу; спеціалісти управління персоналом; система підвищення кваліфікаџїі; курси підвищення кваліфікаџї.

Постановка проблеми. Враховуючи устремління керівництва Міністерства оборони та Збройних Сил України щодо впровадження у військову кадрову політику принципів та підходів, прийнятих в державах членах НАТО, постає чітка необхідність вдосконалення усіх елементів системи кадрового менеджменту, зокрема існуючої системи підвищення кваліфікації фахівців служб персоналу Міністерства оборони та Збройних Сил України.

Потребує аналізу та наукового осмислення іноземний досвід організації навчального процесу на курсах підвищення кваліфікації спеціалістів управління персоналом у збройних силах передових країн світу, зокрема досвід США. В першу чергу це стосується форм та методів навчання, які використовуються під час проведення занять. Подібні знання є одним з найважливіших інструментів впровадження інноваційних ідей у підготовку та проведення навчальних занять на вітчизняних курсах підвищення кваліфікації військових фахівців служб персоналу, що надає можливості для підвищення якості знань та рівня підготовки зазначених фахівців у цілому.

Аналіз останніх досліджень і публікацій. Питання форм та методів навчання, які використовуються під час проведення занять в системі підвищення кваліфікації спеціалістів управління персоналом у збройних силах США, в тій чи іншій мірі розглядалися, у працях таких вітчизняних та зарубіжних науковців як Ю. Бабанський, І. Лернер, М. Скаткін, В. Дикань, П. Сміт, К. Діллон, М. Авалі, У. Кербін, Б. Дейлі, Д. Джонассен та інші. Проте переважна більшість їхніх праць була присвячена вищій школі і лише невелика частина спрямовувалась на вивчення післядипломної освіти та підвищення кваліфікації фахівців. Фактично, проблема узагальнення форм та методів навчання, які використовуються під час проведення занять в системі підвищення кваліфікації фахівців служб персоналу збройних сил США залишається не достатньо вирішеною.

Методи дослідження - теоретичні, зокрема аналіз наукових джерел 3 питань теорії професійної підготовки фахівців служб персоналу збройних сил 
США, теорії та методики викладання спеціальних дисциплін військовим фахівцям; класифікація та систематизація теоретичних даних; конкретизація знань, що стосуються організації навчального процесу з підготовки фахівців служб персоналу; порівняльний аналіз отриманих теоретичних матеріалів.

Метою статті $\epsilon$ здійснення узагальнюючого аналізу форм та методів навчання, які використовуються під час проведення занять у системі підвищення кваліфікації фахівців служб персоналу збройних сил США.

Виклад основного матеріалу. Сучасна загальносвітова стратегія інноваційного навчання передбачає системну організацію управління навчально-виховним процесом. Виділяються три найбільш характерні риси сучасної стратегії навчання: орієнтація на демократичну взаємодію і співпрацю викладача зі слухачами; зміна функції знань і засобів організації їх засвоєння; просування на перший план соціальної природи навчання й розвитку особистості [5, с. 56]. Цим характеристикам інноваційного навчання прямо відповідають програми підвищення кваліфікації фахівців служб персоналу збройних сил США. Тому розкриття специфіки форм та методів навчання в цій системі органічне в межах саме цієї парадигми.

Сучасність наповнює інноваційним змістом фундаментальні дидактичні поняття форми, методи, види, технології навчання тощо. На загальному рівні аналізу розрізняють дві категорії знань - процедурні, які реалізуються в діях (“у процесі”) та декларативні, засвоєння яких передбачає розуміння складових частин і можливість відновити їх. Цей тип знань передбачає також здібність пригадувати інформацію та відновляти їі пізніше $[16,18]$. Залежно від того, чи спрямоване навчання на засвоєння процедурних або декларативних знань, викладач обирає відповідні форми та методи навчання на курсах. [16, 5].

Вчені виокремлюють два види засвоєння інформації, які безпосередньо впливають на зміст і обсяг педагогічної взаємодії під час навчання дериваційне й кореляційне засвоєння. Дериваційне засвоєння може протікати самостійно при належній організації навчальної діяльності, при мінімальному втручанні викладача, але при його постійному спостереженні. Кореляційне засвоєння (співвідносне) передбачає "пояснювальне викладання й рецептивне навчання" коли найбільш абстрактні й загальні положення вводяться на першому етапі навчання особисто викладачем [4, 17; 6, 79]. Дериваційне засвоєння характерне для навчального процесу на курсах підвищення кваліфікації більш високого рівня, а кореляційне - на первинних курсах при першому призначенні до служб персоналу. В цілому, відмінною рисою американської системи підвищення кваліфікації $є$ акцент на самостійному засвоєнні знань слухачем курсів при висококваліфікаційній організації занять викладачем.

За новою моделлю підготовки фахівців, знання є не об'єктом, а засобом розвитку слухача, тобто в результаті навчання знання синтезується слухачем [5, 61]. Ці дидактичні виклики підсилюються ще й самою ситуацією підвищення кваліфікації, цілями та завданнями навчання на цих курсах. Таким чином, зміна якості, ролі та функції знань впливає на формування навчальних завдань i 
відповідно на методи навчання.

Сучасні зарубіжні дослідники розподіляють форми та методи навчання на дві групи - синхронні та асинхронні. Синхронні методи запроваджуються в реальному режимі часу, асинхронні застосовуються 3 відстрочкою, тобто кожний учасник може звернутися до асинхронних методів коли завгодно [15]. Саме темпоральний параметр набуває актуальності для адекватної характеристики процесу навчання в системі підвищення кваліфікації фахівців служб персоналу ЗС США, для якого велике значення набула комбінація безпосередньої аудиторної роботи з опосередкованою роботою за допомогою електронних засобів навчання. Тенденція застосування дистанційної форми навчання набуває сили і в Україні. Наша орієнтація на розгляд навчання в динаміці збігається 3 поглядами багатьох американських дослідників $[15 ; 7 ; 8$; $9 ; 12 ; 14]$. Однак, їхні дослідження методів навчання не надають цілісного уявлення про навчання фахівців служб персоналу у США.

Вітчизняний дослідник Ю. Бабанський виділяє три групи методів: 1) методи організації та здійснення навчально-пізнавальної діяльності; 2) методи стимулювання та мотивації; 3 ) методи контролю та самоконтролю. $[1,110]$.

Розглянемо методи навчання на курсах підвищення кваліфікації спеціалістів по роботі з персоналом згідно з зазначеними групами. До першої групи методів організації та здійснення навчально-пізнавальної діяльності ввійшли: методи роботи 3 літературою, групових обговорень (сократівської бесіди) та презентацій на заняттях, електронних дискусій, письмові завдання тощо. До другої групи методів стимулювання ввійшли: інтерв'ю в керівникапрактика служб персоналу; відвідування приватних структурних елементів служб персоналу; зустріч 3 випускниками цієї програми підвищення кваліфікації, складання професійного портфоліо, ведення журналу професійних діалогів 3 наставником. До третьої групи методів контролю та самоконтролю відносимо оцінювання роботи на занятті викладачем та слухачами, а також оцінювання письмових робіт. У реальній ситуації педагогічної взаємодії в системі підвищення кваліфікації США ці методи виступають у нерозривній єдності, саме тому метод однієї групи може служити прийомом для другої групи методів. Електронні дискусії хоча й належать до групи методів організації навчально-пізнавальної діяльності, але одночасно стимулюють та мотивують слухачів до навчання, тобто виступають прийомом другої групи методів. Спробуємо охарактеризувати зазначені групи методів, виділяючи методичну домінанту в цілісній ситуації педагогічної взаємодії.

Серед найбільш поширених методів навчання першої групи на курсах підвищення кваліфікації фахівців служб персоналу є семінарські заняття як аудиторна форма роботи та організація самостійної роботи слухачів. Поширені на курсах також методи “сократівської бесіди”, електронної презентації та метод дебатів. При цьому, усі завдання слухачам спрямовані на розвиток критичного мислення.

Американські педагоги підкреслюють переваги комбінування традиційних форм роботи 3 дистанційними $[7 ; 9 ; 10]$. Поширення форм дистанційного 
навчання змусило підготувати всю необхідну для навчання інформацію на електронних носіях. Наявність електронних посібників створює більш сприятливі умови і для слухачів стаціонарних груп, які можуть заздалегідь ознайомитися 3 матеріалами лекцій. А на занятті вже проводиться обговорення найбільш складних та проблемних питань. У зв'язку із затребуваністю в Україні дистанційних методів навчання не можна переоцінити значення ознайомлення 3 досвідом успішного використання дистанційних технологій у США.

Американські дослідники відзначають важливість супроводження слухача на шляху пізнання як дистанційного, так і стаціонарного, великого значення надають підтримці й мотивації з боку викладача при застосування синхронних або асинхронних методів викладання. Асинхронні методи дозволяють слухачу міркувати й перевіряти свої думки, таким чином слухач включається до процесу пізнання [19].

Для американської системи підвищення кваліфікації спеціалістів по роботі 3 персоналом характерним $\epsilon$ поєднання різних методів навчання традиційних та сучасних, класичних та специфічних. Широке застосування електронних методів для різних цілей та завдань $є$ суттєвою характеристикою процесу навчання. Використання електронного програмного забезпечення сприяє організації самостійної роботи слухачів курсів. Важливо забезпечити їм доступ до навчальної інформації в будь-який зручний час. Таку можливість надає електронне програмне забезпечення, де викладач розміщує всю інформацію до занять, включаючи навчальні тексти, зразки письмових робіт, аудіо- або відеофайли, а також підтримує електронні дискусії в асинхронному режимі.

Завдяки навчальному програмному забезпеченню американські слухачі мають можливість обговорювати питання за темою між собою і з викладачем поза заняттями, а також розміщувати додаткову корисну інформацію, як-то посилання на джерела. Зрозуміло, що викладач організує пізнавальну діяльність. яка $є$ важливою як для викладача, так і для слухачів. Фактично, викладач виконує дві функції: перша - це планування й управління процесом $\mathrm{i}$ процедурами навчання; друга - це відбір змісту навчання, допомога 3 пошуком джерел. Тобто роль викладача організаційна, а не навчальна $[2,75]$. Але це не виключає навчальної діяльності з боку викладача під час занять.

Крім дискусій в електронному форматі, деякі американські викладачі застосовують засіб “історії навчання”. Цей прийом полягає в зборі різноманітних поглядів на події в організації, такі як реорганізація компанії або запуск нової продукції [11]. Головною метою створювання "історії навчання" $\epsilon$ сприяння "рефлективному обговоренню", результати якого складають своєрідний звіт, де зібрані різноманітні думки та висловлені почуття учасників події. Тобто вплив ідей загального менеджменту, який стає помітним з початку XX сторіччя, дозволив суттєво урізноманітнити також форми та методи роботи зі слухачами курсів підвищення кваліфікації.

Таким чином, варіантів застосування електронного навчального забезпечення для підвищення ефективності занять може бути кілька "історія навчання”, “стіл обговорень” або звичайне листування. Між цими методами є 
спільні й відмінні риси. Однак, сучасні американські педагоги визначають можливість створення менш трудомістких моделей викладання. Це означає зменшення прямого втручання викладача в навчальний процес i надання слухачам можливості знаходити й використовувати навчальний матеріал самостійно. В ідеалі це комбінація самостійного ознайомлення слухачів із заздалегідь підготовленим навчальним матеріалом та взаємодія слухачів 3 викладачем. При цьому викладач зосереджується не на репродукції навчального матеріалу, а на організації педагогічної взаємодії [17]. Саме навчальне програмне забезпечення сприяє такій організації навчального процесу в сучасній системі підвищення кваліфікації фахівців служб персоналу ЗС США.

Найбільш ефективним методом мотивації та стимулювання слухачів $\epsilon$ організація зустрічей 3 практикуючими професіоналами. Аналіз будь-яких проведених інтерв'ю - чи з керівниками служб персоналу, чи з випускниками курсів підвищення кваліфікації, чи 3 працівниками взаємодіючих служб персоналу - $\epsilon$ представленим у письмовому виді відгук, який доповнюється висловлюванням власних поглядів та пропозицій. Такі зустрічі мають велике практичне значення, тому що надають уявлення про специфіку професійних ролей та обов'язків.

Слухачі Курсу спеціаліста з управління персоналом (42A AIT) за період навчання відвідують не менше трьох зустрічей з видатними лідерами роботи 3 персоналом та надають звіт 3 висловленими думками та враженнями від зустрічі. Вивчення цієї форми роботи в США дозволяє зробити висновок про позитивний вплив упровадження нових інтерактивних методів на ефективність навчання. Дійсно, зустрічі з лідерами серед фахівців служб персоналу, які проводилися на базі курсів викликають позитивну реакцію всіх учасників.

Аналіз системи підвищення кваліфікації спеціалістів 3 управління персоналом спирається на тричленну типологію післядипломної освіти, представлену США, а саме: орієнтація на особистість, орієнтація на професію, орієнтація на місце праці [13]. Одним з методів, який дозволяє об'єднати ці три напрямки, є робота слухачів над професійним портфоліо. "Портфоліо - це система організації різних документів з метою конструювання зв'язку між цими документами та концептуальними значеннями. Слухачі можуть включати в портфоліо парадигмальні ствердження або власне розуміння деяких понять, яких вони дотримуються в сучасний період власного життя". Так, наприклад, для початківця у сфері управління персоналом складання професійного портфоліо надає можливість проаналізувати існуючі точки зору на мету й філософію кадрової політики та висловити й оформити власну філософію роботи 3 персоналом, навчання та керування службою персоналу. Протягом професійної діяльності та навчання виникає необхідність перегляду попередніх поглядів, удосконалення деяких професійних аспектів. Головною метою роботи над портфоліо є розробка слухачем власної філософії роботи 3 персоналом, на якій буде будуватися розробка власних поглядів, планів, професійної діяльності загалом. Оцінювання й рефлексія під час вивчення дисциплін курсу підвищення кваліфікації також фіксується в портфоліо у формі заповнених анкет, оглядів 
або виконаних тестів, які можна переглядати під час навчання та далі в професійній праці. Такі документи дають можливість слухачеві усвідомити власні когнітивні та мета-когнітивні процеси [16, 5]

Стосовно форм та методів контролю, що складають третю групу методів, вважаємо, що різноманіття засобів контролю свідчить про гнучкий підхід до навчання слухачів. На думку американських педагогів, наявність таких засобів контролю як традиційні оцінки, опитування, іспити свідчать про урізаність демократії та недостатню довіру до слухачів. Непридатність цих форм та методів контролю для дорослих, які мають досвід та знання, є очевидною. Практикуючі професіонали, коли повертаються до навчання, стають джерелом розвитку для інших завдяки власному багатому та різноманітному досвіду виконання соціальних ролей та життєдіяльності $[18,97]$. Іноді слухачі можуть перевершувати викладача в загальній ерудиції або в конкретних знаннях у сфері власної специфічної діяльності. Якщо викладач сприймає це як загрозу, тоді слухач може йому протистояти й виникає конфліктна ситуація. Конфліктна ситуація знижує ефективність навчання й тому цікаво ознайомитись 3 досвідом залучення слухачів до взаємооцінювання.

На завершальному етапі навчання слухачі заповнюють таблицю, у якій надають оцінку внеску кожного одногрупника до навчання протягом курсу та доповнюють цю оцінку коротким коментарем. Однак, зазначимо, що для конструктивного взаємооцінювання слухачі повинні бути емоційно зрілими й викладачу, необхідно враховувати особисті специфічні риси слухачів.

С кілька засобів ефективно завершити як окреме заняття, так і курс навчання. Згадаємо короткі письмові завдання, якими деякі викладачі завершують заняття (one minute papers). У цій письмовій роботі слухачі відповідають на питання, що важливого вони пізнали на занятті, ставлять запитання за темою, яка вивчається [16, 19]. діляться власними думками стосовно результатів роботи в класі під час заняття. Тобто це $\epsilon$ досить нескладний, але ефективний метод контролю, який відповідає меті особистого та професійного розвитку.

Але головним мірилом підготовки слухачів є заключна письмова робота. Стосовно подібних робіт зауважимо, що сучасна американська кадрова ситуація дає багато матеріалу для дослідження. Тому слухачі, які навчаються на курсі спеціаліста з управління персоналом, обирають дослідження причин зниження кількості бажаючих служити в ЗС США; ефективність рекрутингових заходів; проблеми 3 дисципліною серед військовослужбовців при зміні місця служби. Слухачі, які спеціалізуються в управлінні персоналом, можуть досліджувати тенденції представленості етнічних меншин у військових частинах; наявність соціальної допомоги та ефективність державної підтримки різним групам військовослужбовців тощо.

Висновки та перспективи подальших досліджень. Таким чином, розгляд курсів підвищення кваліфікації фахівців служб персоналу дає змогу простежити, як зазначені три інноваційні напрямки сучасної підготовки органічно впливають на форми та методи навчання на Курсі спеціаліста 3 
управління персоналом. Завдання, що спрямовані на розвиток професійної системи, розповсюджуються між усіма слухачами групи. Взагалі підкреслюється важливість обміну думками під час навчання, діалогу слухачів між собою та з викладачем навіть поза заняттями за допомогою електронної системи спілкування, тобто асинхронно. Узагальнюючи наведену характеристику методів навчання, ще раз підкреслимо пряму залежність методів від цілей навчання, що детально розробляються в програмах курсів підвищення кваліфікації фахівців служб персоналу США.

У результаті аналізу методів, форм та технологій навчання зроблено висновок про їх залежність від мети, завдань та змісту підвищення кваліфікації. У реальному навчальному процесі методи існують не окремо, а в нерозривній єдності, доповнюють один одного.

Для американських курсів спеціалістів управління персоналом характерним $€$ поєднання традиційних та специфічних методів навчання. Під специфічним розуміємо використання інтерактивних методів навчання в сукупності із застосуванням комп'ютерних технологій, спрямованих на досягнення різних цілей та завдань. Спільним для різних комп'ютерних технологій є ефективна комбінація самостійної роботи слухачів та сприяння творчій роботі з новим знанням. Тобто викладач відходить від репродуктивного навчання та зосереджується на організації продуктивного навчального середовища. Завдяки навчальному програмному забезпеченню така модель навчання $€$ менш трудомісткою та відповідає сучасним потребам слухачів.

Для впровадження зазначених методів підрозділи підвищення кваліфікації забезпечують відповідну інфраструктуру - домовленість 3 керівниками навчальних закладів, урахування в позааудиторному навантаженні викладача часу на організацію та контроль самостійної роботи слухачів. Результатом застосування цих методів є успішна реалізація поставленої мети та завдань навчання за програмою курсів управління персоналом.

Виходячи з матеріалів статті у подальшому вбачається перспективним дослідження специфіки та особливостей застосування цих форм та методів у навчальному процесі в системі підвищення кваліфікації фахівців служб персоналу збройних сил провідних іноземних держав, з метою впровадження кращих напрацювань в систему підвищення кваліфікації фахівців служб персоналу Міністерства оборони та Збройних Сил України.

\section{ЛІТЕРАТУРА}

1. Бабанский Ю. К. Оптимизация педагогического процесса : (в вопросах и ответах) / Ю. К. Бабанский, М. М. Поташкин. 2-е изд., перераб. и доп. Киев : Рад. шк., 1983. 287 с.

2. Вульфсон Б. Л. Последипломное образование в развитых странах. Педагогика. 1993. № 3. C. 86 - 92 .

3. Дикань В.С. Рефлексивный подход в теории и практике подготовки будущих педагогов в университетах США (педагогический аспект) : дис. ... канд. пед. наук : 13.00.04. Симферополь, $1999.212 \mathrm{c}$.

4. Подосенова Е. А. Проблема взаимодействия преподавателя и слухачов в педагогике высшей школы США (критический анализ) : автореф. дис. ... канд. пед. наук : 13.00.01. Москва, 1985. 27 с. 
5. Чернилевский Д. В. Дидактические технологии в высшей школе : учеб. пособ. Москва : ЮНИТИ-ДАНА, 2002. 437 с. $156 \mathrm{p}$.

6. Austin A. Achieving Educational Excellence / Austin A. San Francisco : Jossey-Bass, 1985.

7. Avali M. Computer mediated collaborative learning: An empirical evaluation / M. Avali // MIS Quarterly. 1994. Vol.18, No 2. P. 159 - 174.

8. Cerbin W. The course portfolio as a tool for continuous improvement of teaching and learning / W. Cerbin // Journal of Excellence in College Teaching. 1994. Vol.5, No 1. P. 95 - 105.

9. Daley B. J. Novice to expert: an exploration of how professionals learn / B. J. Daley // Adult Education Quarterly. 1999. Vol. 49, No 4. P. 1.

10.Eaton M. Searching for the „New" University: Changing Faculty Roles / Marie Eaton // Working Papers № 2, Project on the Future of Higher Education. Western Washington University. 2002. 14 p.

11.Guidelines for preparing programme specifications. The Quality Assurance Agency for Higher Education - Gloucester, 2006. 15 p.

12.Isaacson R. Integration within the Scholarship of Teaching: When Teachers become I earners in Foreign Disciplines R. Isaacson // Journal of Scholarship of Teaching and Learning. 2001. Vol. 2, No 1. P. 1 - 5.

13.Johnston R. Institutional and Interorganizational Contexts of Educational Administrator Preparation / R. Johnston // The Urban Review. 1991. Vol. 23, No 1. P. 31 - 38.

14.Kleiner A., Roth G., Thomas T., Hamel E. Oil Change: Perspectives on Corporate Transformation / Kleiner A., Roth G. New York: Oxford University Press, 2000.

15.Marks N., O'Connel R. Using Statistical Control Charts to Analyze Data from Student Evaluations of Teaching / Marks Neil B., O'Connel Richard T. // Decision Science Journal of Innovative Education. Vol. 1, No 2. Fall 2003. P. 259 - 272.

16.Murphy J., Forsyth P. Educational Administration: A Decade of Reform / Murphy J., Forsyth P. A Sage Publication Company, Thousand Oaks : California, 1999. 283 p.

17.National Council for Accreditation on Teacher Education. URL: http:// www.ncate.org.

18. NDEA 21: A Renewed Commitment to Graduate Education. The Council of Graduate Schools. Final statement. Nov. 2005. URL: http://www.cgsnet.org/pdf/NDEA21 Final.pdf.

19.Smith P.L., Dillon C.L. Comparing distance learning and classroom learning: Conceptual consideration / P. L. Smith, C. L. Dillon // American Journal of Distance Education. 1999. Vol. 13, No 2. P. 6 - 23.

\section{REFERENCES}

1. Babanskiy Yu. (1983). Optimizatsiya pedagogicheskogo protsessa: (v voprosah i otvetah) [Optimization of the pedagogical process: (in questions and answers)]. 2-e izd., pererab. i dop. Kyiv : Rad. shk., 287 (in Ukrainian).

2. Vulfson B. L. (1993). Poslediplomnoe obrazovanie v razvityih stranah [Postgraduate education in developed countries]. Pedagogika, 3, 86 - 92 (in Russian).

3. Dikan V.S(1999). Refleksivnyiy podhod v teorii i praktike podgotovki buduschih pedagogov v universitetah SShA (pedagogicheskiy aspekt) [Reflexive approach in the theory and practice of training future teachers in US universities (pedagogical aspect)]. Simferopol, 212 (in Ukrainian).

4. Podosenova E. A. (1985). Problema vzaimodeystviya prepodavatelya i sluhachov v pedagogike vyisshey shkolyi SShA (kriticheskiy analiz) [The problem of teacher interaction and hearing in pedagogy of higher education in the USA (critical analysis)]. Moscow,. - $27 \mathrm{~s}$ (in Russian).

5. Chernilevskiy D. V. (2002). Didakticheskie tehnologii v vyisshey shkole [Didactic technology in high school]. Moscow : YuNITI-DANA, 437 (in Russian).

6. Austin A. (1985). Achieving Educational Excellence. San Francisco : Jossey-Bass, 156. 
7. Avali M. (1994). Computer mediated collaborative learning: an empirical evaluation. MIS Quarterly, 18 (2), 159 - 174.

8. Cerbin W. (1994). The course portfolio as a tool for continuous improvement of teaching and learning. Journal of Excellence in College Teaching, 5 (1), 95 - 105.

9. Daley B. J. Novice to expert: an exploration of how professionals learn. Adult Education Quarterly, 49 (4), 1.

10. Eaton M. (2002). Searching for the „New" University: Changing Faculty Roles. Working Papers \# 2, Project on the Future of Higher Education. Western Washington University, 14.

11. Guidelines for preparing programme specifications. (2006). The Quality Assurance Agency for Higher Education - Gloucester, 15 p.

12. Isaacson R. (2001). Integration within the Scholarship of Teaching: When Teachers become I earners in Foreign Disciplines. Journal of Scholarship of Teaching and Learning, 2 (1), $1-5$.

13. Johnston R. (1991). Institutional and Interorganizational Contexts of Educational Administrator Preparation. The Urban Review, 23 (1), 31 - 38.

14. Kleiner A., Roth G., Thomas T., Hamel E. (2000). Oil Change: Perspectives on Corporate Transformation. New York: Oxford University Press.

15. Marks N., O'Connel R. (2003). Using Statistical Control Charts to Analyze Data from Student Evaluations of Teaching. Decision Science Journal of Innovative Education, 1 (2), 259 272.

16. Murphy J., Forsyth P. (1999). Educational Administration: A Decade of Reform. Sage Publication Company, Thousand Oaks : California, 283.

17. National Council for Accreditation on Teacher Education. URL: http:// www.ncate.org.

18. NDEA 21 : A Renewed Commitment to Graduate Education. The Council of Graduate Schools. Final statement. Nov. 2005. URL: http://www.cgsnet.org/pdf/NDEA21 Final.pdf.

19. Smith P.L., Dillon C.L. (1999). Comparing distance learning and classroom learning: Conceptual consideration. American Journal of Distance Education, 13 (2), 6 - 23.

\section{РЕЗЮМЕ}

директор Департамента кадровой политики Министерства обороны Украины

\section{Формы и методы повышения квалификации специалистов служб́ персонала вооруженных сил США}

В статье выполнен анализ форм и методов обучения, используемых в системе повышения квалификащии специалистов служб персонала вооруженных сил США; рассмотрены основные направления исследований зарубежных и отечественных ученых в этой области; определень основные группь методов обучения слушателей и их составляющие; проанализировань особенности использования преподавателями курсов повышения квалификации различных форм и методов обучения в ходе проведения занятий.

Ключевые слова: формы и методы обучения; специалисты служб персонала; специалисты управления персоналом; система повыщения квалификации; курсы повышения квалификации. 


\title{
SUMMARY
}

\author{
Oleg Yacyno, \\ Director of Personnel Policy \\ Ministry of Defense of Ukraine
}

\section{Forms and methods of advanced training of US military personnel}

Introduction. Taking into account the aspirations of the leadership of the Ministry of Defense and the Armed Forces of Ukraine to implement the principles and approaches adopted in the NATO member states in the military personnel policy, there is a clear need to improve all elements of the personnel management system, in particular, the existing system for the training of specialists of the personnel services of the Ministry of Defense and Armed Forces of Ukraine.

The purpose of the article is to carry out a generalized analysis of the forms and methods of training that are used during the training in the system of advanced training of specialists of the services of personnel of the US armed forces.

Research methods are theoretical, in particular, the analysis of scientific sources on the theory of professional training of specialists in the services of the personnel of the armed forces of the USA; specification of knowledge related to the organization of the training process for the training of specialists in the services of personnel; comparative analysis of the received theoretical materials.

Results. The article analyzes the modern forms and methods of training used in the current system of advanced training of specialists of the US Armed Forces personnel and identifies the possibilities for introducing American experience into the national system. The author considers the main directions of research of foreign and domestic scientists in the field of studying the forms and methods of training used in the training courses for the personnel of the personnel of the US Armed Forces. The types of assimilation of information that influence the use of forms and methods during the training of specialists of the personnel services are established.

The article provides an opportunity to trace how the three innovative directions of modern training studied organically influence the forms and methods of training in the course of a human resource specialist. The article describes the main groups of methods used in the training of US military personnel at advanced training courses and discloses their main components. The author analyzes the peculiarities of the use by teachers of advanced training courses of various forms and methods of training in the course of conducting classes. The direct dependence of methods on the goals of training, which is elaborated in the programs of courses of advanced training of specialists of US personnel services, is established.

Originality. The practical significance of the results of the study is the introduction of better experience of the armed forces of the advanced countries of the world in the system of training of specialists of the personnel services of the Ministry of Defense and the Armed Forces of Ukraine.

Conclusion. The result of the application of the defined forms and methods of training used in the system of training of specialists of the US Armed Forces personnel is the successful realization of the goal and objectives of the training program of the personnel management courses.

Subsequently, it is envisaged to study the specifics and peculiarities of the application of these forms and methods in the educational process in the system of training of specialists of the personnel services of the armed forces of the leading foreign states for the further introduction of the best practices in the system of professional development of specialists of the personnel services of the Ministry of Defense and the Armed Forces of Ukraine.

Key words: forms and methods of training; specialists of personnel services; specialists of personnel management; system of professional development; advanced training courses. 